\title{
Modyfikacja struktury i właściwości napoin wykonanych łukiem krytym
}

\author{
Modification of structure and properties \\ of padding welds made by submerged arc surfacing
}

\section{Streszczenie}

W artykule przedstawiono wyniki prób modyfikacji struktury i właściwości napoin wykonanych łukiem krytym spoiwem niskowęglowym przez wprowadzenie do jeziorka ciekłego metalu proszku metalicznego na osnowie niklu wraz ze zmienną zawartością $\mathrm{Al}_{2} \mathrm{O}_{3}$ oraz SiC. Określono wpływ parametrów napawania na wymiary geometryczne napoin oraz udział materiału rodzimego w napoinie. Wykonane napoiny proste oraz zakładkowe zostały poddane badaniom nieniszczącym, badaniom metalograficznym, pomiarom twardości, a także badaniom odporności na zużycie ścierne typu metal-minerał.

\section{Abstract}

The article presents the results of modification of structure and properties of submerged-arc surfacing padding welds. To modification is by the nickel-base flux with variable $\mathrm{Al}_{2} \mathrm{O}_{3}$ and $\mathrm{SiC}$ mass fraction addition into the arc weld pool. The process parameters influence on the geometrical dimensions of the padding weld and base material in the padding weld is observed. The simple and overlap padding welds have been non-destructive testing, metallographic examinations, hardness distribution measurements and resistance to abrasive wear of metal-mineral joints investigating.

\section{Wstęp}

Ograniczona trwałość części maszyn i urządzeń powoduje ciągły rozwój i udoskonalanie metod naprawy i regeneracji zużytych elementów. W praktyce poszczególne części maszyn nie są obciążone w jednakowym stopniu, dlatego wykonuje się je z różnych materiałów, które mają za zadanie zapewnić im jak najdłuższą trwałość. Do tego celu wykorzystuje się również metody polepszania właściwości powierzchni, takie jak: hartowanie, nawęglanie i azotowanie. Jedną z coraz częściej stosowanych metod poprawy właściwości powierzchni narażonych na zużycie jest napawanie. Które ma wiele zalet $w$ porównaniu $z$ innymi metodami, a przede wszystkim grubość nałożonej warstwy jest dowolna. Skład chemiczny napoiny

Dr inż. Jacek Górka, dr inż. Artur Czupryński, dr inż. Tomasz Kik, mgr inż. Michał Piotrowski - Politechnika Śląska, Gliwice. również nie jest ściśle określony, można go zmieniać i dobierać w zależności od wymagań i rodzaju zużycia, jakiemu poddany jest element. Podstawowymi czynnikami powodującymi zużycie części maszyn i urządzeń mogą być: tarcie, erozja, oddziaływanie temperatury, odkształcenia itp. Działanie tych czynników może powodować konieczność wymiany lub regeneracji części, co wiąże się z kosztami samych części, jak również z kosztami spowodowanymi postojem maszyn. Podstawowym celem regeneracji jest uzupełnianie lub odtwarzanie warstw zużytych w czasie eksploatacji. Metody spawalnicze wykorzystuje się również przy produkcji nowych części maszyn i urządzeń. Napawanie produkcyjne stosuje się do pokrywania nowych elementów warstwą wierzchnią zwiększającą odporność na: korozję, zużycie ścierne, kawitację, erozję lub zwiększającą żaroodporność i żarowytrzymałość. Materiały stosowane na napoiny mające wysokie właściwości eksploatacyjne mogą pochodzić ze wszystkich grup materiałowych, metali i stopów, cermetali, ceramiki oraz tworzyw sztucznych. Podczas napawania warstwę metalu, zwykle o odmiennym składzie chemicznym, układa 
się na podłożu części napawanej. Są dwa warunki, które musi spełniać ułożona $w$ ten sposób napoina: musi mieć właściwości zapewniające trwałość w warunkach pracy przewidzianych dla tego elementu oraz odpowiedni kształt, a zwłaszcza grubość i szerokość. Wymagane właściwości może zapewnić odpowiednio dobrany skład chemiczny, natomiast kształt napoiny uzależniony jest od metody, parametrów i techniki napawania $[1 \div 8]$.

\section{Badania własne}

Celem badań było przeprowadzenie prób modyfikacji struktury i właściwości napoin wykonanych

Tablica I. Skład chemiczny i właściwości mechaniczne stali S355J2 Table I. Chemical composition and mechanical properties of S355J2 steel

\begin{tabular}{|c|c|c|c|c|c|}
\hline \multicolumn{5}{|c|}{ Zawartość pierwiastków, \% } \\
\hline $\mathrm{C}$ & $\mathrm{Si}$ & $\mathrm{Mn}$ & $\mathrm{Cu}$ & $\mathrm{P}$ & $\mathrm{S}$ \\
\hline 0,2 & 0,55 & 1,6 & 0,55 & 0,025 & 0,025 \\
\hline \multicolumn{5}{|c|}{ Właściwości mechaniczne } \\
\hline $\begin{array}{c}\text { Wytrzymałość na roz- } \\
\text { ciąganie } \mathrm{R}_{\mathrm{m}}, \mathrm{MPa}\end{array}$ & $\begin{array}{c}\text { Granica plastycz- } \\
\text { ności } \mathrm{R}_{\mathrm{e}}, \mathrm{MPa}\end{array}$ & Praca łamania, J \\
\hline \multicolumn{2}{|c|}{355} & \multicolumn{2}{c|}{27} \\
\hline
\end{tabular}

Tablica II. Skład chemiczny i właściwości mechaniczne stopiwa drutu OK Autrod 12.20

Table II. Chemical composition and mechanical properties of wire weld material OK. Autrod 12.20

\begin{tabular}{|c|c|c|}
\hline \multicolumn{3}{|c|}{ Zawartość pierwiastków, \% } \\
\hline $\mathrm{C}$ & $\mathrm{Si}$ & $\mathrm{Mn}$ \\
\hline 0,08 & 0,3 & 1,35 \\
\hline \multicolumn{3}{|c|}{ Właściwości mechaniczne } \\
\hline $\begin{array}{c}\text { Wytrzymałość na roz- } \\
\text { ciąganie } \mathrm{R}_{\mathrm{m}}, \mathrm{MPa}\end{array}$ & Wydłużenie $\mathrm{A}_{5}, \%$ & $\begin{array}{c}\text { Praca } \\
\text { łamania, J }\end{array}$ \\
\hline $480-650$ & 29 & 80 \\
\hline
\end{tabular}

Tablica III. Skład chemiczny i właściwości proszku niklowego EuTroLoy $16223 \mathrm{G}$

Table III. Chemical composition and mechanical properties of nickel-base powder EuTroLoy 16223G

\begin{tabular}{|c|c|c|c|c|c|c|}
\hline \multicolumn{7}{|c|}{ Zawartość pierwiastków, \% } \\
\hline $\mathrm{Ni}$ & $\mathrm{C}$ & $\mathrm{Cr}$ & $\mathrm{B}$ & $\mathrm{Si}$ & $\mathrm{Fe}$ & $\mathrm{Al}$ \\
\hline osnowa & 0,3 & 7 & 1,3 & 3,1 & $<3$ & 1 \\
\hline \multicolumn{6}{|c|}{ Właściwości proszku } \\
\hline \multicolumn{3}{|c|}{ Wielkość ziaren, $\mu \mathrm{m}$} & \multicolumn{3}{c|}{ Twardość, HRC } \\
\hline \multicolumn{3}{|c|}{$32-125$} & \multicolumn{3}{c|}{34} \\
\hline
\end{tabular}

Tablica IV. Wybrane właściwości fizyczne $\mathrm{Al}_{2} \mathrm{O}_{3}$ i $\mathrm{SiC}$

Table IV. Selected physical properties of $\mathrm{Al}_{2} \mathrm{O}_{3}$ and $\mathrm{SiC}$

\begin{tabular}{|c|c|c|c|c|}
\hline \multicolumn{5}{|c|}{ Właściwości $\mathrm{Al}_{2} \mathrm{O}_{3} / \mathrm{SiC}$} \\
\hline $\begin{array}{c}\text { Twardość } \\
\mathrm{H} / \mathrm{E}{ }^{*}\end{array}$ & $\begin{array}{c}\text { Temp. top- } \\
\text { nienia, }{ }^{\circ} \mathrm{C}\end{array}$ & $\begin{array}{c}\text { Temp. } \\
\text { pracy, }{ }^{\circ} \mathrm{C}\end{array}$ & $\begin{array}{c}\text { Odporność na } \\
\text { utlenianie, }{ }^{\circ} \mathrm{C}\end{array}$ & $\begin{array}{c}\text { Gęstość } \\
\mathrm{g} / \mathrm{cm}^{3}\end{array}$ \\
\hline $6 \times 10^{-2}$ & $2450 / 2500$ & $1400 / 1500$ & $1350 / 1400$ & $4,1 / 3,3$ \\
\hline \multicolumn{5}{|c}{$[\mathrm{H} / \mathrm{E}]-$ twardość H odniesiona do modułu Younga E } \\
\hline
\end{tabular}

łukiem krytym na podłożu ze stali S355J2 (tabl. I), z zastosowaniem drutu OK Autrod 12.20 oraz topnika OK Flux 10.71 (tabl. II) przez wprowadzenie do jeziorka ciekłego metalu proszku na osnowie niklu EuTroLoy $16223 G$ (tabl. III), ze zmiennym udziałem wagowym $\mathrm{Al}_{2} \mathrm{O}_{3}$ oraz $\mathrm{SiC}$ (tabl. IV).

\section{Optymalizacja parametrów napawania}

W celu określenia optymalnych parametrów napawania ściegów zakładkowych przeprowadzono proces napawania ściegów prostych na zautomatyzowanym stanowisku spawalniczym w pozycji podolnej (rys. 1). Wykonano 9 napoin, stosując zmienne parametry na-

Tablica V. Parametry technologiczne zastosowane do wykonania ściegów prostych napoin

Table V. The technological parameters used for string beads of padding welds

\begin{tabular}{|c|c|c|c|c|}
\hline $\begin{array}{c}\mathrm{Nr} \\
\text { napoiny }\end{array}$ & $\begin{array}{c}\text { Natężenie } \\
\text { prądu I, A }\end{array}$ & $\begin{array}{c}\text { Napięcie } \\
\text { łuku U, V }\end{array}$ & $\begin{array}{c}\text { Prędkość } \\
\text { napawania } \\
\text { v, cm/min }\end{array}$ & $\begin{array}{c}\text { Energia } \\
\text { liniowa E, } \\
\mathrm{kJ} / \mathrm{cm}\end{array}$ \\
\hline 1 & 300 & 30 & 50 & 11 \\
\hline 2 & 400 & 30 & 50 & 14 \\
\hline 3 & 500 & 30 & 50 & 18 \\
\hline 4 & 300 & 35 & 50 & 13 \\
\hline 5 & 400 & 35 & 50 & 17 \\
\hline 6 & 500 & 35 & 50 & 21 \\
\hline 7 & 300 & 40 & 50 & 14 \\
\hline 8 & 400 & 40 & 50 & 19 \\
\hline 9 & 500 & 40 & 50 & 24 \\
\hline
\end{tabular}

Tablica VI. Jakość i właściwości napoin jednościegowych napawanych łukiem krytym

Table VI. The quality and properties of one-bead padding welds submerged arc surfacing

\begin{tabular}{|c|l|c|}
\hline $\begin{array}{c}\text { Numer } \\
\text { napoiny }\end{array}$ & \multicolumn{1}{c|}{ Jakość napoiny } & $\begin{array}{c}\text { Udział mate- } \\
\text { riału rodzime- } \\
\text { go w napoinie } \\
U_{p}, \%\end{array}$ \\
\hline 1 & $\begin{array}{l}\text { Nierównomierne lico, chropowatość po- } \\
\text { wierzchni, bardzo mała ilość pęknięć }\end{array}$ & 30,2 \\
\hline 2 & $\begin{array}{l}\text { Równe lico napoiny, chropowatość po- } \\
\text { wierzchni, duża ilość pęknięć }\end{array}$ & 34,6 \\
\hline 3 & $\begin{array}{l}\text { Równe lico napoiny, niewielka chropowatość } \\
\text { powierzchni, bardzo duża ilość pęknięć }\end{array}$ & 49,1 \\
\hline 4 & $\begin{array}{l}\text { Równe lico, chropowatość powierzchni, } \\
\text { bardzo mała ilość pęknięć }\end{array}$ & 27,7 \\
\hline $5 *$ & $\begin{array}{l}\text { Równe lico napoiny, niewielka chropo- } \\
\text { watość powierzchni, mała ilość pęknięć }\end{array}$ & 37,9 \\
\hline 6 & $\begin{array}{l}\text { Równe lico napoiny, niewielka chropowa- } \\
\text { tość powierzchni, bardzo duża ilość pęknięć }\end{array}$ & 51,6 \\
\hline 7 & $\begin{array}{l}\text { Równe lico, duża chropowatość po- } \\
\text { wierzchni, duża ilość pęknięć }\end{array}$ & 40,9 \\
\hline 8 & $\begin{array}{l}\text { Równe lico napoiny, chropowatość po- } \\
\text { wierzchni, bardzo duża ilość pęknięć }\end{array}$ & 52,9 \\
\hline * parametry wytypowane do wykonania napoin zakładkowych \\
\hline tość powierzchni, duża ilość pękniéć
\end{tabular}




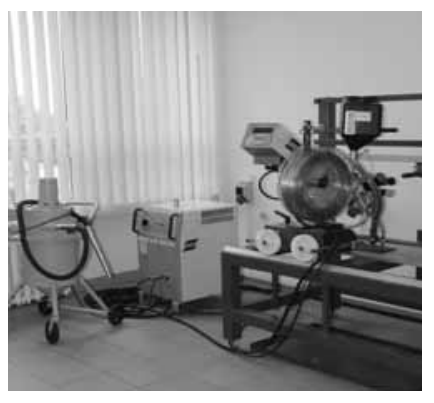

Rys. 1. Widok stanowiska spawalniczego oraz sposobu podawania proszku metalicznego

Fig. 1. The view of welding station and the method of powder supply

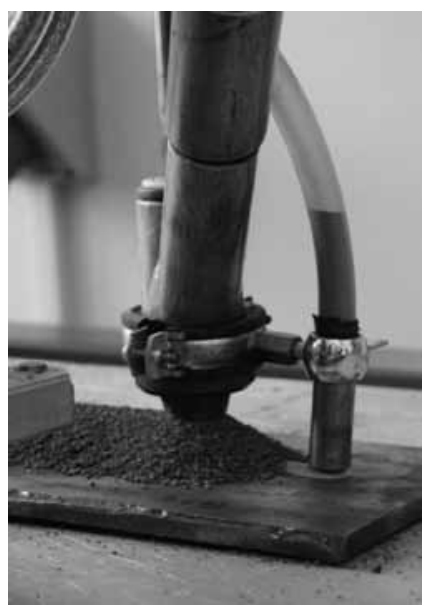

pawania na podłożu ze stali S355J2 z zastosowaniem drutu OK Autrod 12.20 o średnicy $3,2 \mathrm{~mm}$ oraz topnika OK Flux 10.71 z dodatkiem proszku EuTroLoy 16223G, długość napoin wynosiła ok. $250 \mathrm{~mm}$ (tabl. V).

Uzyskane napoiny poddano badaniom wizualnym, penetracyjnym, metalograficznym makroskopowym, pomiarom twardości oraz określono ich wymiary geometryczne, a także udział materiału rodzimego w napoinie. Badania te pozwoliły na ocenę jakości napoin oraz wytypowanie parametrów do dalszej części badań (tabl. VI).

\section{Wykonanie napoin zakładkowych}

W celu modyfikacji struktury i właściwości wykonano dwie serie napoin zakładkowych z zastosowaniem drutu OK Autrod 12.20 oraz proszku EuTroLoy 16223G: I seria $\mathrm{z}$ dodatkiem $\mathrm{Al}_{2} \mathrm{O}_{3}$, II. seria $\mathrm{z}$ dodatkiem $\mathrm{SiC}$ o udziale wagowym w proszku w obu przypadkach $0,5,10,15$ i $20 \%$. Parametry napawania dobrane na podstawie wykonanych wstępnych badań napoin pojedynczych wynosiły:

- natężenie prądu I-400 A,

- napięcie łuku U - $35 \mathrm{~V}$,

- prędkość napawania $v-50 \mathrm{~cm} / \mathrm{min}$,

- energia liniowa $\mathrm{E}-17 \mathrm{~kJ} / \mathrm{cm}$,

- natężenie podawania proszku - $80 \mathrm{~g} / \mathrm{min}$,

- zakładka ściegu - 50\%.

Uzyskane napoiny poddano badaniom wizualnym i penetracyjnym (rys. 2, 3).
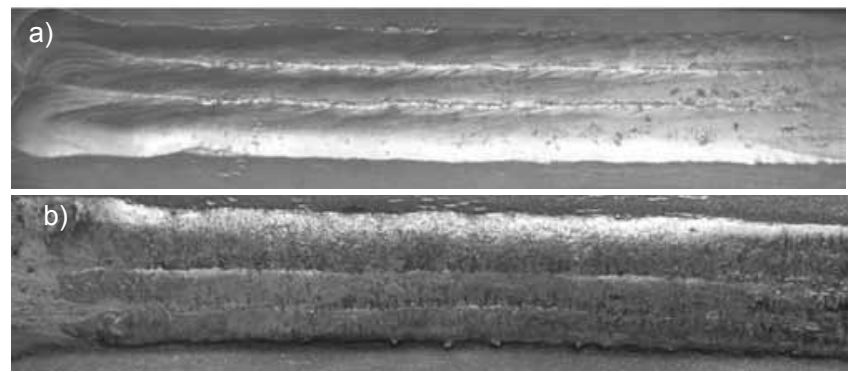

Rys. 2. Lico przykładowych napoin wykonanych łukiem krytym z: a) $10 \%$ dodatkiem $\mathrm{Al}_{2} \mathrm{O}_{3}$, b) $15 \%$ dodatkiem $\mathrm{SiC}$

Fig. 2. The face of selected pudding welds made by submerged weIding arc with: a) $10 \% \mathrm{Al}_{2} \mathrm{O}_{3}$ addition, b) $15 \% \mathrm{SiC}$ addition

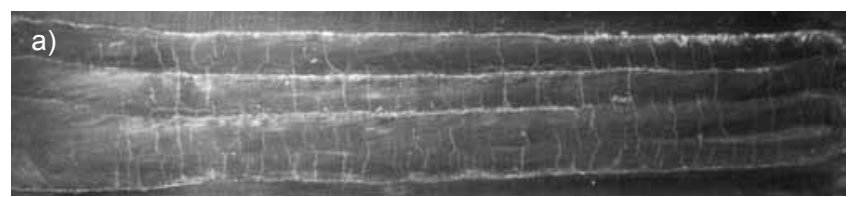

b)

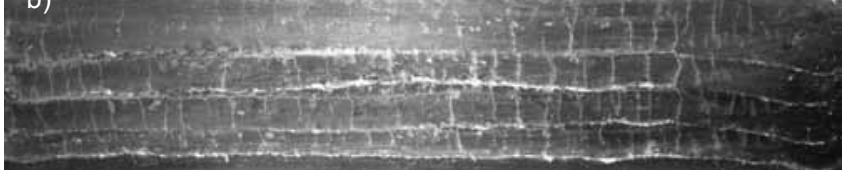

Rys. 3. Lico przykładowych napoin wykonanych łukiem krytym po badaniach penetracyjnych $\mathrm{z}$ : a) $5 \%$ dodatkiem $\mathrm{Al}_{2} \mathrm{O}_{3}$, b) $20 \%$ dodatkiem SiC

Fig. 3. The face of selected pudding welds made by submerged weIding arc after penetrating tests with: a) $5 \% \mathrm{Al}_{2} \mathrm{O}_{3}$ addition, b) $20 \%$ $\mathrm{SiC}$ addition

\section{Badania metalograficzne}

W celu określenia wpływu dodatku proszku EuTroLoy $16223 \mathrm{G}$ oraz $\mathrm{Al}_{2} \mathrm{O}_{3}$ i SiC na strukturę uzyskanych napoin wykonano badania metalograficzne makroskopowe na mikroskopie stereoskopowym Olympus SZX9 (rys. 4) oraz badania metalograficzne mikroskopowe na mikroskopie świetlnym Olympus PME 3 (rys. 5, 6).
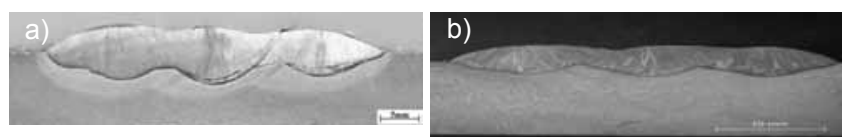

Rys. 4. Makrostruktury przykładowych napoin wykonanych łukiem krytym z: a) $10 \%$ dodatkiem $\mathrm{Al}_{2} \mathrm{O}_{3}$, b) $15 \%$ dodatkiem $\mathrm{SiC}$

Fig. 4. Macrostructures of selected padding welds made by submerged arc surfacing: a) $10 \% \mathrm{Al}_{2} \mathrm{O}_{3}$ addition, b) $15 \% \mathrm{SiC}$ addition
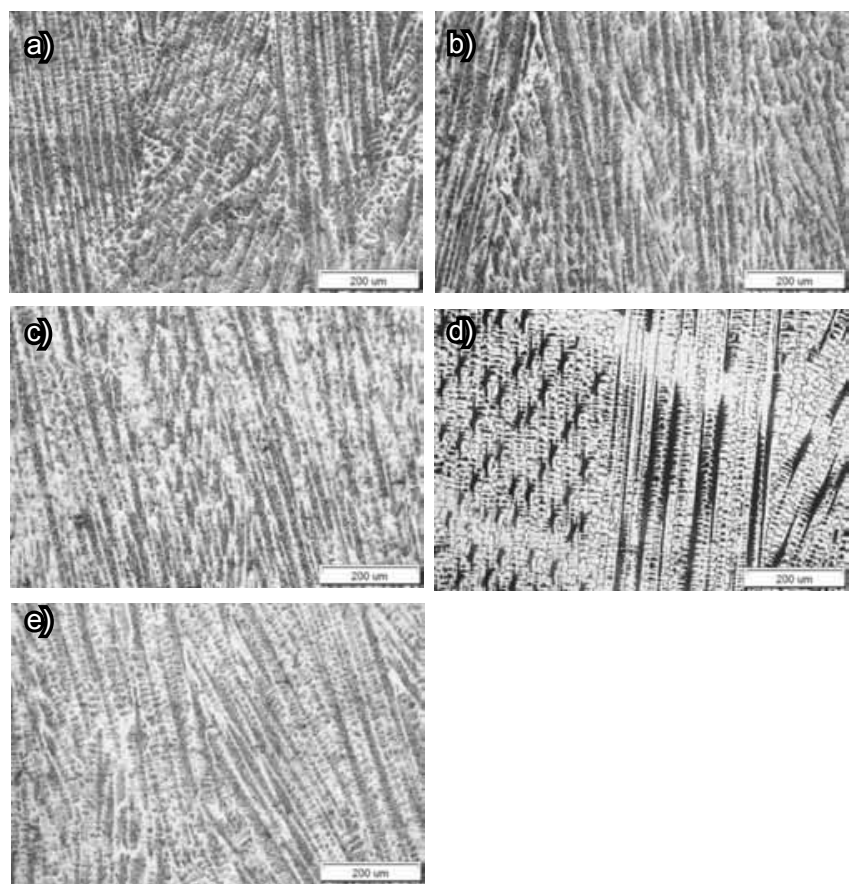

Rys. 5. Mikrostruktury napoin wykonanych przy zmiennym udziale $\mathrm{Al}_{2} \mathrm{O}_{3}$ w proszku EuTroLoy 16223G: a) bez $\mathrm{Al}_{2} \mathrm{O}_{3}$, b) $5 \% \mathrm{Al}_{2} \mathrm{O}_{3}$, c) $10 \% \mathrm{Al}_{2} \mathrm{O}_{3}$, d) $15 \% \mathrm{Al}_{2} \mathrm{O}_{3}$, e) $20 \% \mathrm{Al}_{2} \mathrm{O}_{3}$

Fig. 5. The microstructures of padding welds made with variable $\mathrm{Al}_{2} \mathrm{O}_{3}$ addition in EuTroLoy $16223 \mathrm{G}$ addition: a) without $\mathrm{Al}_{2} \mathrm{O}_{3}$, b) $5 \% \mathrm{Al}_{2} \mathrm{O}_{3}$, c) $10 \% \mathrm{Al}_{2} \mathrm{O}_{3}$, d) $15 \% \mathrm{Al}_{2} \mathrm{O}_{3}$, e) $20 \% \mathrm{Al}_{2} \mathrm{O}_{3}$ 

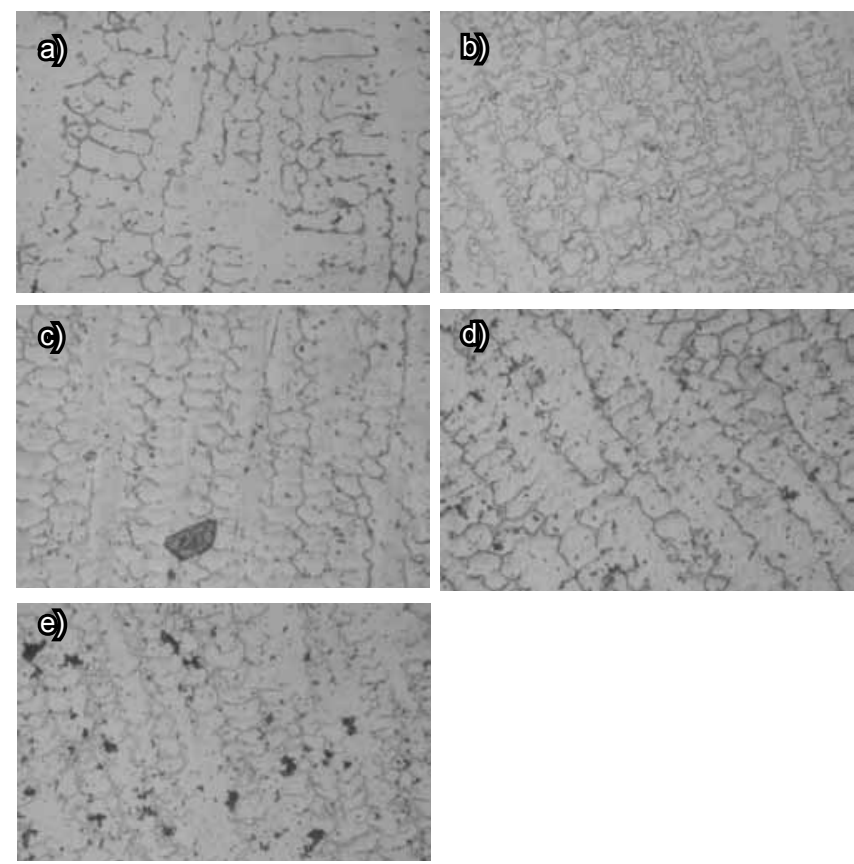

Rys. 6. Mikrostruktury napoin wykonanych przy zmiennym udziale SiC w proszku EuTroLoy 16223G: a) bez SiC, b) $5 \% \mathrm{SiC}$, c) $10 \% \mathrm{SiC}$, d) $15 \% \mathrm{SiC}$, e) $20 \% \mathrm{SiC}$

Fig. 6. The microstructures of padding welds made with variable $\mathrm{SiC}$ addition in EuTroLoy $16223 \mathrm{G}$ addition: a) without $\mathrm{SiC}$, b) $5 \% \mathrm{SiC}$, c) $10 \% \mathrm{SiC}$, d) $15 \% \mathrm{SiC}$, e) $20 \% \mathrm{SiC}$

\section{Pomiary twardości}

W celu określenia twardości powierzchni po napawaniu wykonano pięć pomiarów na przeszlifowanym licu napoin i odniesiono je do twardości stali Hardox 400. Badania przeprowadzono na twardościomierzu Rockwella przy obciążeniu $1471 \mathrm{~N}$ trwającym $4 \mathrm{~s}$. Wyniki pomiarów twardości przedstawiono w tablicy VII.

\section{Badanie odporności na zużycie ścierne typu metal-minerał}

Badania odporności na zużycie ścierne warstw kompozytowych napawanych łukiem krytym drutem

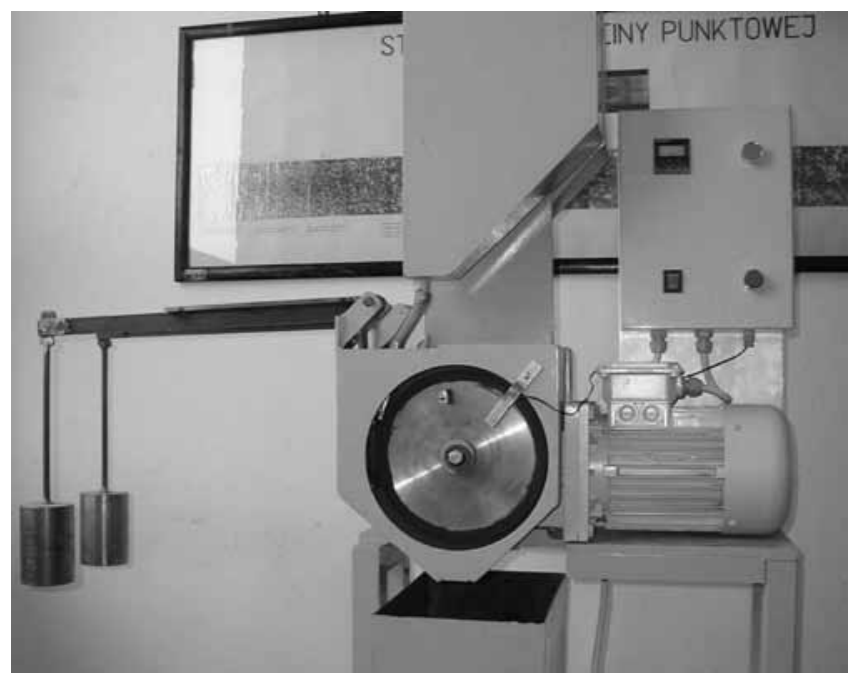

Rys. 7. Stanowisko do prób odporności na zużycie ścierne zgodnie z norma ASTM G 65

Fig. 7. Stadion for abrasive wear resistant testing acc. to ASTM G-65

z dodatkiem proszku niklowego ze zmiennym udziatem wagowym $\mathrm{Al}_{2} \mathrm{O}_{3}$ oraz $\mathrm{SiC} \mathrm{w}$ odniesieniu do stali Hardox 400 wykonano zgodnie $z$ norma ASTM $G$ 65-00, Procedure A (rys. 7) [9]. Próbki o wymiarach $75 \times 25 \times 10 \mathrm{~mm}$ wycięto ze środka napoin kompozytowych zakładkowych oraz stali Hardox 400 i przeszlifowano (rys. 8). Wszystkie próbki, zgodnie z zaleceniami normy ASTM G 65-00, przed i po próbie ścieralności, ważono na wadze laboratoryjnej $z$ dokładnością do 0,0001 g. Ubytek masy próbek napawanych łukiem krytym porównano bezpośrednio z ubytkiem masy próbek ze stali HARDOX 400. Wykorzystując zmierzoną gęstość napoin kompozytowych i ubytek masy próbek, obliczono objętościowy ubytek masy (tabl. VIII).

Do obliczenia ubytku objętościowego użyto wzoru:

$$
U_{o}=\frac{U_{m}}{\rho} \times 1000
$$

gdzie: $U_{o}$ - ubytek objętościowy, $\mathrm{mm}^{3} ; U_{\mathrm{m}}$ - ubytek masy, g; $\rho$ - gęstość, $\mathrm{g} / \mathrm{cm}^{3}$.

Tablica VII. Wyniki pomiarów twardości napoin na przeszlifowanym licu

Table VII. The hardness test on the grinded face of the padding weld

\begin{tabular}{|c|c|c|c|c|c|c|}
\hline \multicolumn{6}{|c|}{ Oznaczenie napoiny } & Wartość średnia \\
\hline \multicolumn{7}{|c|}{ Napoiny wykonane $\mathrm{z}$ dodatkiem $\mathrm{Al}_{2} \mathrm{O}_{3}$} \\
\hline $0 \% \mathrm{Al}_{2} \mathrm{O}_{3}$ & 27,5 & 27,3 & 27,5 & 26,0 & 28,5 & 27,4 \\
\hline $5 \% \mathrm{Al}_{2} \mathrm{O}_{3}$ & 28,5 & 27,2 & 30,1 & 27,3 & 28,6 & 28,3 \\
\hline $10 \% \mathrm{Al}_{2} \mathrm{O}_{3}$ & 27,6 & 28,5 & 28,7 & 29,7 & 30,5 & 29,0 \\
\hline $15 \% \mathrm{Al}_{2} \mathrm{O}_{3}$ & 29,1 & 27,9 & 29,2 & 28,3 & 28,7 & 28,6 \\
\hline $20 \% \mathrm{Al}_{2} \mathrm{O}_{3}$ & 28,5 & 28,2 & 30,8 & 30,3 & 29,2 & 29,4 \\
\hline \multicolumn{7}{|c|}{ Napoiny wykonane $\mathrm{z}$ dodatkiem SiC } \\
\hline $0 \% \mathrm{SiC}$ & 28,5 & 28,0 & 27,5 & 27,0 & 26,8 & 27,6 \\
\hline $5 \% \mathrm{SiC}$ & 29,0 & 32,2 & 33,1 & 32,3 & 28,5 & 31,0 \\
\hline $10 \% \mathrm{SiC}$ & 29,3 & 30,5 & 29,0 & 30,7 & 31,5 & 30,2 \\
\hline $15 \% \mathrm{SiC}$ & 29,3 & 28,5 & 30,2 & 31,8 & 28,4 & 29,6 \\
\hline $20 \% \mathrm{SiC}$ & 30,0 & 28,6 & 28,3 & 29,7 & 31,2 & 29,7 \\
\hline \multicolumn{7}{|c|}{ Twardość stali Hardox 400} \\
\hline $\mathrm{H} 400$ & 41,6 & 39,8 & 40,9 & 42,1 & 43,6 & 41,6 \\
\hline
\end{tabular}



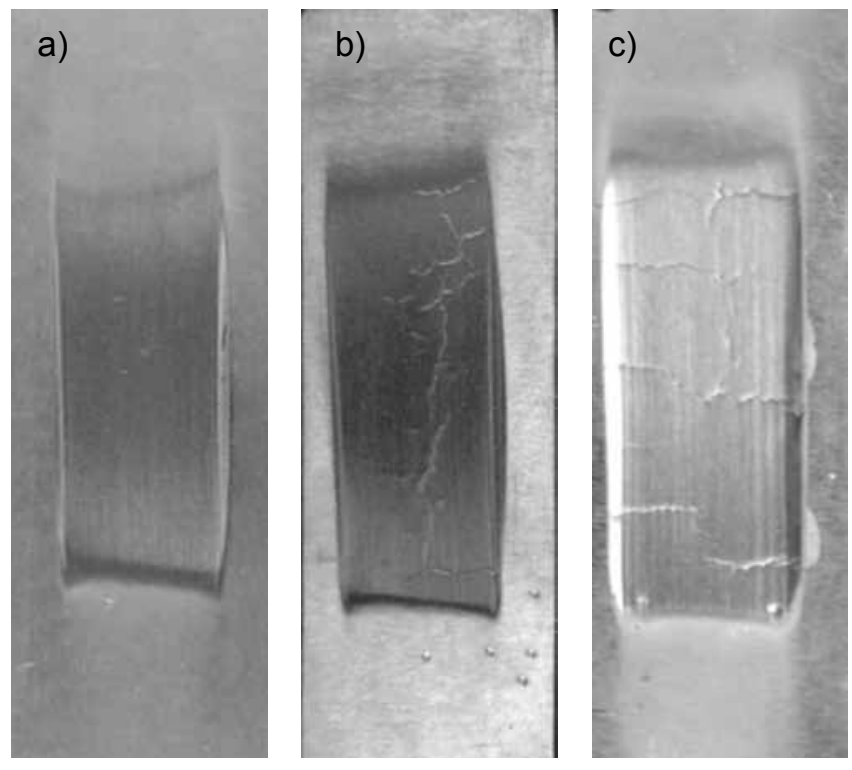

Rys. 8. Przykładowe próbki po badaniach odporności na zużycie ścierne: a) stal Hardox 400 , b) napoina $\mathrm{z} 10 \% \mathrm{Al}_{2} \mathrm{O}_{3}, \mathrm{c}$ ) napoina $\mathrm{z}$ $15 \% \mathrm{SiC}$

Fig. 8. Samples after abrasive wear resistant tests: a) Hardox 400 steel, b) padding weld with $10 \% \mathrm{Al}_{2} \mathrm{O}_{3}$ addition, c) padding weld with $15 \% \mathrm{SiC}$ addition

Tablica VIII. Wyniki badań odporności na zużycie ścierne typu metal-minerał warstw kompozytowych napawanych łukiem krytym z odniesieniem do odporności na zużycie ścierne stali Hardox 400 przeprowadzonych zgodnie z normą ASTM G 65-00

Table VIII. The abrasive wear resistant test results of submerged arc surfacing padding welds with metal-mineral composite layers in comparison to the abrasive wear resistance of Hardox 400 steel made acc. to ASTM G 65-00

\begin{tabular}{|c|c|c|c|c|c|c|}
\hline $\begin{array}{l}\text { Numer } \\
\text { próbki }\end{array}$ & $\begin{array}{c}\text { Masa przed } \\
\text { testem } \\
\mathrm{g}\end{array}$ & $\begin{array}{l}\text { Masa po } \\
\text { teście } \\
g\end{array}$ & $\begin{array}{l}\text { Ubytek masy } \\
\text { g }\end{array}$ & $\begin{array}{l}\text { Gęstość } \\
\mathrm{g} / \mathrm{cm}^{3}\end{array}$ & $\begin{array}{l}\text { Ubytek objęto- } \\
\text { ściowy } \\
\mathrm{mm}^{3}\end{array}$ & $\begin{array}{l}\text { Względna odpornośćc } \\
\text { na ścieranie* }\end{array}$ \\
\hline \multicolumn{7}{|c|}{ Napoiny wykonane $\mathrm{z}$ dodatkiem $\mathrm{Al}_{2} \mathrm{O}_{3}$} \\
\hline $0 \% \mathrm{Al}_{2} \mathrm{O}_{3}$ & 136,4350 & 133,6922 & 2,7428 & 7,93 & 345,8764 & 0,52 \\
\hline $5 \% \mathrm{Al}_{2} \mathrm{O}_{3}$ & 114,7488 & 112,0734 & 2,6754 & 7,83 & 341,6858 & 0,53 \\
\hline $10 \% \mathrm{Al}_{2} \mathrm{O}_{3}$ & 144,2087 & 141,6650 & 2,5437 & 7,73 & 329,0686 & 0,55 \\
\hline $15 \% \mathrm{Al}_{2} \mathrm{O}_{3}$ & 144,0592 & 141,6093 & 2,4499 & 7,67 & 319,4133 & 0,56 \\
\hline $20 \% \mathrm{Al}_{2} \mathrm{O}_{3}$ & 149,9705 & 147,5836 & 2,3869 & 7,63 & 312,8309 & 0,57 \\
\hline \multicolumn{7}{|c|}{ Napoiny wykonane $z$ dodatkiem SiC } \\
\hline $0 \% \mathrm{SiC}$ & 104,8267 & 102,0941 & 2,7326 & 7,95 & 343,7233 & 0,52 \\
\hline $5 \% \mathrm{SiC}$ & 111,6530 & 109,0716 & 2,5814 & 7,81 & 330,5250 & 0,54 \\
\hline $10 \% \mathrm{SiC}$ & 150,8819 & 148,4360 & 2,4459 & 7,76 & 315,1933 & 0,57 \\
\hline $15 \% \mathrm{SiC}$ & 115,1468 & 112,8125 & 2,3343 & 7,77 & 300,4271 & 0,60 \\
\hline $20 \% \mathrm{SiC}$ & 116,4705 & 113,8495 & 2,2210 & 7,73 & 287,3221 & 0,62 \\
\hline \multicolumn{7}{|c|}{ Stal Hardox 400} \\
\hline $\mathrm{H} 400$ & 58,3280 & 56,9366 & 1,3914 & 7,75 & 179,5355 & 1 \\
\hline
\end{tabular}

\section{Podsumowanie}

Badania wizualne napoin zakładkowych wykonanych parametrami dobranymi na podstawie prób napawania ściegów pojedynczych z zakładką 50\%, nie wykazały nieprawidłowości dotyczących kształtu i wyglądu lica napoin. Badania penetracyjne uwidoczniły pęknięcia w kierunku prostopadłym do kierunku napawania. Pęknięcia nie pro- pagują do podłoża materiału rodzimego i nie powinny negatywnie wpływać na właściwości użytkowe takie jak odporność na zużycie ścierne. Pęknięcia te mają prawdopodobnie charakter pęknięć gorących, co jest związane ze składnikami wprowadzanego proszku metalicznego (rys. 9). Badania mikroskopowe wykazały, że napoiny charakteryzują 


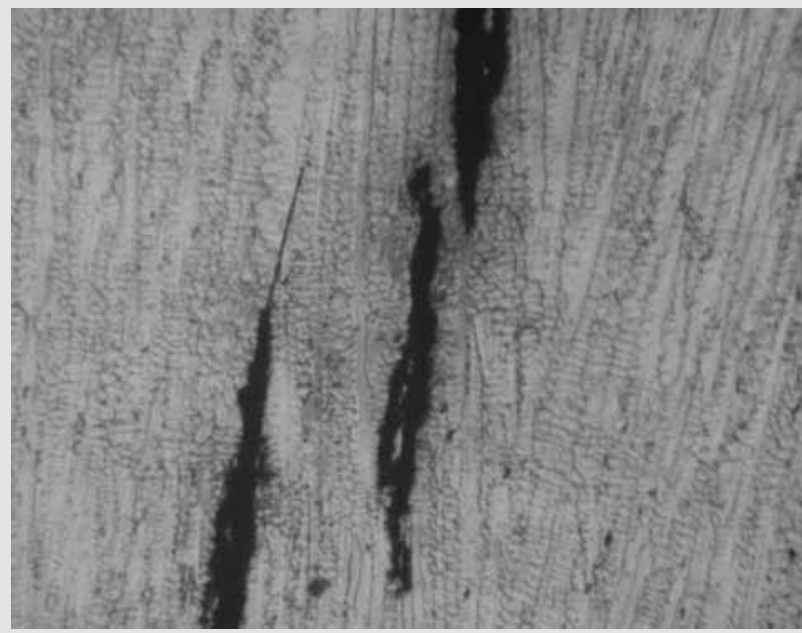

Rys. 9. Pęknięcie napoiny $z$ dodatkiem $15 \% \mathrm{SiC}$

Fig. 9. Crack of pad welding with $15 \% \mathrm{SiC}$ addition

się strukturą austenityczną $z$ wydzielonymi eutektykami węglikowymi i borkowymi powstałymi w wyniku wprowadzenia do napoiny proszku EuTroLoy $16223 \mathrm{G}$ na osnowie niklu $z$ dodatkiem boru i chromu. W napoinach można zaobserwować węgliki SiC. Wysoka temperatura jeziorka ciekłego metalu oraz jego duża objętość prowadzi do znacznego rozpuszczenia wprowadzanego dodatku $\mathrm{Al}_{2} \mathrm{O}_{3}$ oraz $\mathrm{SiC}$ w osnowie austenitycznej (rys. 10). Pomiary gęstości uzyskanych napoin wykazały, że wraz ze wzrostem udziału wagowego $\mathrm{Al}_{2} \mathrm{O}_{3}$ oraz $\mathrm{SiC}$ w napoinach maleje ich gęstość, co pozwala stwierdzić, że dodatki te znajdują się w napoinach w stanie rozpuszczonym.

Pomiary twardości na przeszlifowanym licu napoin wykazały, że twardość napoin wykonanych $\mathrm{z}$ dodatkiem proszku metalicznego $\mathrm{i} \mathrm{Al}_{2} \mathrm{O}_{3}$ wynosi ok. 28 HRC, natomiast napoin wykonanych

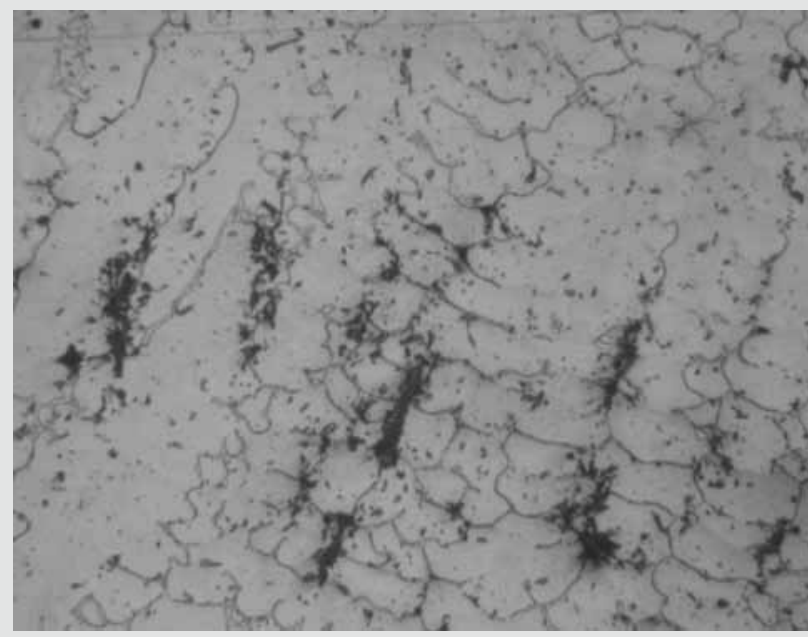

Rys. 10. Częściowo rozpuszczonych węglików $\mathrm{SiC}$ w napoinie z 20\% dodatkiem SiC

Fig. 10. Partially deposited SiC carbon in the padding weld with $20 \% \mathrm{SiC}$ addition

z dodatkiem proszku metalicznego i SiC ok. 30 HRC. Twardość uzyskana na powierzchni jest wynikiem powstania struktur $z$ wymieszania się materiału podłoża ze spoiwem, proszkiem metalicznym oraz dodatkami $\mathrm{Al}_{2} \mathrm{O}_{3}$ oraz $\mathrm{SiC}$. Pomiary nie wykazały wyraźnego wpływu ilości wprowadzonego $\mathrm{Al}_{2} \mathrm{O}_{3}$ oraz $\mathrm{SiC}$ na twardość powierzchni lica napoin. Badania odporności na zużycie ścierne wykazały, że wzrost udziału wagowego $\mathrm{Al}_{2} \mathrm{O}_{3}$ oraz $\mathrm{SiC}$ w proszku metalicznym nieznacznie wpływa na podwyższenie odporności na zużycie ścierne typu metal-minerał. W przypadku napoin $\mathrm{z}$ dodatkiem $\mathrm{Al}_{2} \mathrm{O}_{3}$ odporność na zużycie ścierne wynosi $0,53 \div 0,57$ w stosunku do stali Hardox 400, a w napoinach z do-

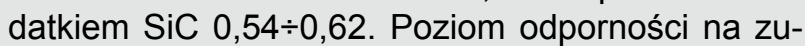
życie ścierne uzależniony jest od rozmieszczenia wprowadzanych dodatków oraz od ich skłonności do rozpuszczania w ciekłym jeziorku napoin.

\section{Literatura}

[1] Goldsberry C.: The Basics of Submerged Arc Welding, Welding Magazine, No. 8/2008.

[2] Karaoglu S., Secgin A.: Sensitivity analysis of submerged arc welding process parameters, Journal of Materials Processing Technology, 2008.

[3] Farrow N., Studholme S.: Submerged arc welding with fused flux and basic cored wire for low temperature applications, Svetsaren Nr. 1/2000.

[4] Tušek J.: Metal-powder twin-wire submerged-arc welding, Welding \& Metal Fabrication, No 8/1998.

[5] Ambroza P., Bendikiene R., Kavaliauskiene L.: Submerged arc surfacing of structural steel using metal powder added to flux, Conference on Heat Transfer, Thermal Engineering and Environment, Athens, Greece, 2007.
[6] Aruna S., Diwakar S., Jain A., Rajam K.: Comparative study on the effect of current density on $\mathrm{Ni}$ and $\mathrm{Ni}-\mathrm{Al}_{2} \mathrm{O}_{3}$ nanocomposite coatings produced by electrolytic deposition, Surface Engineering, Vol. 21, 2005.

[7] Dong S., Beake B., Parkinson R., Xu B., Hu Z., Bell T.: Determination of hardness and Young's modulus of brush plated nano-Al2O3/Ni composite coating by nanoindentation testing, Surface Engineering, Vol. 19, No. 3, 2003.

[8] Grum J., Kejžar R., Slabe J.: Submerged arc surfacing of NiCo-Mo alloys similar to maraging steels on a structural steel, Journal of Materials Processing Technology, 2004.

[9] ASTM G65 - 04: Standard test method for measuring abrasion using the dry sand/rubber wheel apparatus 